\title{
Review
}

\section{Non-Chemical Approaches to Control Postharvest Gray Mold Disease in Bell Peppers}

\author{
Charles Krasnow and Carmit Ziv *(D)
}

check for updates

Citation: Krasnow, C.; Ziv, C. Non-Chemical Approaches to Control Postharvest Gray Mold Disease in Bell Peppers. Agronomy 2022, 12, 216. https://doi.org/ 10.3390/agronomy12010216

Academic Editor: Anastasios Darras

Received: 1 December 2021 Accepted: 12 January 2022 Published: 16 January 2022

Publisher's Note: MDPI stays neutral with regard to jurisdictional claims in published maps and institutional affiliations.

Copyright: (C) 2022 by the authors. Licensee MDPI, Basel, Switzerland. This article is an open access article distributed under the terms and conditions of the Creative Commons Attribution (CC BY) license (https:// creativecommons.org/licenses/by/ $4.0 /)$.
Department of Postharvest Science, Agricultural Research Organization, Volcani Institute, Rishon LeZion 7505101, Israel; charlesk@volcani.agri.gov.il

* Correspondence: Carmit.Ziv@volcani.agri.gov.il; Tel.: +972-3-9683610

\begin{abstract}
Bell pepper (Capsicum annuum) is a widely grown vegetable crop that is nutritious and flavorful and economically important for growers worldwide. A significant limiting factor in the postharvest storage and long-distance transport of peppers is gray mold caused by Botrytis cinerea. The pathogen is widespread in nature, highly aggressive, and able to cause disease at cool refrigerated temperatures during transport and storage. Fungicides have been relied on in the past to reduce bell pepper rots in storage; however, concern over residues on the fruit and environmental degradation have heightened the importance of natural and generally recognized as safe (GRAS) solutions that effectively limit disease. Essential oils, plant extracts, inorganic chemicals, biocontrols, defense activators, hot water treatments, and modified storage conditions have been tested to reduce losses from gray mold. Despite significant amounts of research on natural methods of control of $B$. cinerea postharvest, research specific to gray mold in peppers is limited. The objective of this review is to summarize the research conducted with environmentally friendly alternatives to chemical fungicides to control this important pathogen of peppers postharvest. To ensure a steady supply of healthy and nutritious produce, more research is needed on the development, use, and application of nonhazardous Botrytis control methods. Until an effective solution is found, using a combined approach including environmental controls, sanitation, and GRAS products remain paramount to limit Botrytis fruit rot of peppers postharvest.
\end{abstract}

Keywords: postharvest; solanaceae; integrated pest management; fungicides; GRAS; biological control; gray mold

\section{Introduction}

Bell pepper is one of the most important vegetable crops grown worldwide for fresh consumption and processing. There are five domesticated species of capsicum and over 20 wild ancestors; however, Capsicum annuum is the most widely cultivated [1]. C. annuum has high horticultural value due to its pungency, flavor, and nutritional qualities, adding color, flavor, and texture to many fresh and processed products. In the Mediterranean region, the pepper crop is grown during the winter and summer months for export and local markets. High-quality fruits are uniform in shape, bright in color, large, firm, and without blemishes [2,3]. In North America, the blocky bell pepper with four lobes is preferred, as well as pungent chili peppers [1]. Bell peppers are typically produced in the open field and in greenhouses [4]. In many regions, the pepper crop is grown in shade structures and other forms of protected cultivation [5]. A major constraint to pepper production are diseases from fungal and bacterial pathogens [6]. The most important pathogens infecting pepper fruit during the growing season include Botrytis cinerea, Colletotrichum spp., Alternaria spp., Phytophthora capsici, and Xanthomonas spp. [7,8]. Protected cultivation reduces some stresses on the plants from intense sun and wind that provide entry for pathogens; however, temperature and humidity fluctuation still occurs, allowing for dew 
formation and disease causing organisms to infect $[9,10]$. Even in arid regions, disease pressure during the growing season remains significant due to humidity and dew formation [9]. Once harvested, peppers are typically washed, packaged, and stored at cool $\left(2-10{ }^{\circ} \mathrm{C}\right)$ temperatures prior to sales. This environment is optimal for fruit quality and allows transit to distant markets; however, certain disease causing organisms can produce significant damage prior to marketing including B. cinerea, Alternaria spp., Rhizopus stolonifer, and Erwinia spp. B. cinerea is one of the most important postharvest pathogens due to its ability to grow at low temperatures, aggressiveness, and distribution. It is generally accepted that losses for perishable vegetables postharvest are high [11], and B. cinerea has a significant role in reducing fruit quality in developed and developing countries [6]. The economic costs of postharvest Botrytis fruit rot is variable, and significant market losses due to the pathogen have been reported [7,12]. In Mediterranean or dry temperate areas, fruit rot during storage and transport were significant $[13,14]$. In Pakistan growing regions, Botrytis fruit rot was estimated at approx. 25\% [15].

\section{Pathogen Life Cycle}

B. cinerea can cause disease during all phases of pepper crop production, but is primarily a pathogen of the fruit $[7,14]$. In the field, greenhouse, and protected houses, spores are present on the ground, in debris, and from neighboring diseased plants $[9,10,16]$. The pathogen is ubiquitous in the environment and conidia spread readily via air currents. High levels of conidia in pepper and eggplant poly-greenhouses have been recorded using sporesamplers in Spain [17]. In Korea, cool nights $\left(15^{\circ} \mathrm{C}\right)$ and warm days were most conducive for $B$. cinerea outbreaks and high spore loads in pepper growing greenhouses [18]. When conditions favor disease, conidia are formed on infected plant parts in grape-like clusters and are released with changes in relative humidity and wind [10]. After conidia land on susceptible plants and fruit, they germinate, form a germ tube, and infect. Initial symptoms include water-soaked and slightly sunken spots. The lesions quickly coalesce and form large discolored and soft regions of the fruit, resulting in complete loss [7]. The pathogen grows rapidly when environmental conditions are favorable $\left(18-24{ }^{\circ} \mathrm{C} ;>93 \% \mathrm{RH}\right)$ and can quickly destroy susceptible plants, flowers, and postharvest commodities $[8,10]$. B. cinerea can survive in debris [19] or as sclerotia and chlamydospores [10]. Once plants become infected, spread by conidia is most important.

\section{Aspects of the Postharvest Disease Cycle}

B. cinerea affects many specialty crops and flowers postharvest. The pathogen is able to cause disease from $0-26^{\circ} \mathrm{C}[7,20]$, allowing it to cause disease in postharvest storage at cool temperatures [21]. The source of postharvest outbreaks is not always evident; fruit can be infected directly from inoculum present on neighboring fruit, from latent infections, or at wound sites $[7,14]$. Rots are insidious and often do not appear until the fruit arrive at retail setting; shipments with a significant percentage of infected fruit may be rejected by the broker. The disease cycle of postharvest fruit rot of pepper caused by $B$. cinerea has not been fully elucidated but likely shares similarities with other fruiting vegetables [7]. Postharvest fungal diseases of pepper fruit caused by Alternaria alternata and Fusarium spp. enter the fruit via natural openings. A. alternata was able to enter pepper fruit via the blossom end of the fruit and cause internal rots postharvest [22], while the calex-end of the pepper appears to be an important area of entry for Fusarium subglutinans [23] and Erwinia carotovora [24]. These may also be avenues for B. cinerea infection in addition to direct penetration of the cuticle. The pepper cuticle is very thick and lacking stomata [25]; however, microscopic cracks are apparent, which may be an entry site or provide nutrients for B. cinerea conidia [26]. Available nutrients and sugars on the host surface are important for successful infection $[27,28]$. B. cinerea is known to produce numerous enzymes, including cutinase, pectolytic enzymes, and cellulase, which allow for dissolution of the cuticle and infection to progress [28]. B. cinerea has also been observed on sunscalded areas of pepper fruit and anywhere where wounds are apparent [14]. Extended 
periods at cool temperatures were suggested as possibly enhancing gray mold postharvest. Cold temperatures weaken the cuticle and cell structure, which can reduce resistance to the pathogen [29]. Using early harvesting as a technique to limit disease as is practiced with citrus, avocado, and other fruits is not an option for the fresh market sales of bell peppers due to the defined changes in antioxidants, carotenoids, flavonoids, and sugars of the fruit and other desired characteristics that develop with fruit ripening [30].

\section{Trends in Fungicide Use}

Intensive agriculture has resulted in an increase in agrochemical use across all cropping systems [31]. Fungicides have been heavily relied upon in specialty crop production to limit losses from $B$. cinerea infection pre- and postharvest $[10,13,32,33]$. Over the last 15 years, scrutiny of agrochemicals has increased, and numerous compounds have been removed from the market [34]. Restrictions in agrochemical use due to governmental regulations, consumer concerns over residues and environmental degradation, and the development of extensive fungicide resistance has led to the search for natural compounds with fungicidal activity [31,35]. Maximum residue limits are used by governmental agencies to determine if the residues present in foodstuffs are dangerous to consumers [36]. In general, agrochemical residues on produce in developed countries are low [37]; however, the potential for toxic residues exists. Residues on fruit are a heightened concern, making control of postharvest diseases of fruiting vegetables a unique challenge to the industry. There are very few fungicides that can be applied to produce postharvest to limit losses from B. cinerea, depending on the crop and market. For freshly consumed vegetables, there are often no fungicides labeled for use, with few notable exceptions, including citrus and apples [38]. Research on biological compounds with fungicidal activity has increased significantly to meet market demands and alleviate concerns over residues [39], and these compounds are increasingly important for growers. In addition to toxic residue concerns, fungicide resistance is regularly observed in many fungi [40]. B. cinerea is a highly variable pathogen and well documented as able to overcome commonly used fungicides [41,42]. Resistance mechanisms to benzimidazole and dicarboximide classes of chemistries have been described [43,44]. Over-production of ATP-binding cassette transporters was the mechanism of resistance to the anilinopyrimidines, an important class of fungicides [32]. Reports of resistance to Fludioxanil [45] cyprodinil [46] and the recently developed succinate dehydrogenase inhibitors (SDHIs) fluopyram, fluxapyroxad, and penthiopyrad [47] have highlighted the need to find alternatives. Liu et al. [33] tested $B$. cinerea isolates from tomato greenhouses in China and found that resistance to the SDHI fungicide Boscalid was moderate, potentially reducing the effectiveness of fungicide management programs. The challenges of managing B. cinerea with traditional fungicide chemistries are manifold and an integrated approach that reduces reliance on chemicals is needed for continued successful production and postharvest storage of bell peppers.

\section{Alternatives to Fungicides}

Due to the high level of interest in natural and generally regarded as safe (GRAS) products to control gray mold postharvest, numerous compounds including essential oils and volatiles, plant extracts, agricultural by-products, inorganic chemicals, biocontrols, and plant defense activators have been researched [48-52]. In addition, UV light, environmental regulation, hot water treatment, and sanitation have been researched and found to have an effect on $B$. cinerea development of fruiting vegetables in storage (Table 1). Postharvest processing and storage is considered an ideal location for the use of biocontrols because it is a controlled environment, protected from UV and precipitation, and the implementation of control strategies is practical with equipment already present in many operations. There is a good opportunity to optimize formulations to take advantage of organisms that are adapted for specific conditions postharvest [53]. 
Table 1. Reports of physical, chemical, microbial, or environmental treatments effective against gray mold of bell pepper (Capsicum annuum L.) postharvest.

\begin{tabular}{|c|c|c|c|}
\hline $\begin{array}{l}\text { Biocontrol } \\
\text { Treatment }\end{array}$ & $\begin{array}{l}\text { Method of } \\
\text { Biocontrol } \\
\text { Application }\end{array}$ & Fungicidal Effect & Reference \\
\hline Modified atmosphere & $\mathrm{NaCl}$ pouches & Reduced fungal growth & [54] \\
\hline Hot water & Rinse and brush & Direct, Host alteration & [55] \\
\hline Hinokitiol oil & Fruit dip & Direct fungicidal & [49] \\
\hline VOCs from cinnamon oil & Sealed container & $\begin{array}{c}\text { Fungicidal, } \\
\text { fumigant effect }\end{array}$ & [56] \\
\hline Olive oil mill wastewater & Fruit dip & $\begin{array}{l}\text { Induced response, } \\
\text { phenolic compounds }\end{array}$ & [57] \\
\hline Potassium bicarbonate & Fruit dip & Direct, fungistatic & [58] \\
\hline Hydrogen peroxide & Fruit dip & $\begin{array}{l}\text { Direct, inhibition of spore } \\
\text { germination }\end{array}$ & [48] \\
\hline Harpin protein & $\begin{array}{c}\text { Foliar sprays } \\
\text { preharvest }\end{array}$ & $\begin{array}{l}\text { Host physiology } \\
\text { alteration }\end{array}$ & [59] \\
\hline Multiple bacterial species & Pipette & Antagonistic suppression & [60] \\
\hline
\end{tabular}

\subsection{Essential Oils and Agricultural By-Products}

A strong desire to identify compounds that are safe to humans and the environment has resulted in the development of numerous plant oils and extracts as biofungicides [61,62]. These compounds are bioactive compounds with high antifungal activity [38]. Essential oils have been researched intensively for activity against $B$. cinerea and other pathogens. Wilson, et al. [63] tested over 300 essential oils and extracts for activity against $B$. cinerea isolates and found 13 with high antifungal activity. The concentrations tested ranged from $0.39-100 \%$. The researchers suggested that these compounds could be used as safe alternatives to conventional pesticides as both fungicides and fumigants. Hinokitiol, an oil extract from Japanese Cyprus, inhibited B. cinerea growth in vitro and prevented gray mold on bell peppers dipped in a solution at $750 \mu \mathrm{L} / \mathrm{L}$ [49]. This compound disintegrates the plasma membrane of B. cinerea and genes for pathogenicity are downregulated [64]. Vapors from sage essential oils reduced postharvest pepper rot [65], while volatiles of cinnamon oil did not prevent $B$. cinerea infection [56]. Peppers that were inoculated prior to cinnamon oil treatment rotted. Cinnamon oil at $500 \mathrm{ppm}$ in vitro completely inhibited mycelial growth of $B$. cinerea, and $100 \mathrm{ppm}$ reduced growth; conidial germination was reduced but not prevented at any concentration [56]. Clove and olive oil $(0.125-0.5 \%)$ have also been tested and found to reduce $B$. cinerea in vitro and limit fungal growth on peppers when applied as a pre-harvest spray [66]. Natural agricultural by-products such as compost water extracts [67] and olive oil mill waste water [57] can control gray mold of pepper; however, formulations must be optimized to facilitate practical application. The reduction in fungal growth from olive oil mill waste water may have been due to a systemic response or direct fungicidal action, as both peroxidase and phenolperoxidase activity were increased in fruits after 2-5 days in storage and may be involved with the defense response of the fruit [57].

\subsection{Chitin and Chitosan}

Chitin and chitosan are natural polymers that are safe to consumers and the environment and able to prevent diseases of numerous crops caused by B. cinerea postharvest [68]. Chitin is an abundant biopolymer extracted from exoskeletons of crustaceans and is widely regarded as safe for human consumption. Chitosan, a polymer of $\beta-1,4$-linked D-glucosamine, has known activity against $B$. cinerea, damaging hyphal cell walls that come in contact with the compound [69] and activating the fruits defense response against 
the pathogen [70]. These compounds have been tested against numerous pathogens for effective and safe disease control [71]. Chitin and chitosan are available in various forms, which may provide different levels of disease control when used alone or in combination with a microbial formulation or essential oil [72,73]. The yeast Candida utilis and chitosan prevented tomato fruit rot at 0.25 and $0.5 \%$, and chitosan at concentrations from $0.025-1.0 \%$ inhibited A. alternata and Geotrichum candidum germination in vitro [74]. Cucumber plants treated with chitosan $(0.1 \%)$ showed lower gray mold disease severity levels than control plants when inoculum was applied before and after treatment [75]. Longer time intervals after treatment prior to inoculation resulted in greater levels of control. Tomatoes treated with chitosan plus Ruta graveolens essential oil coating had significantly lower incidence of gray mold growth and higher quality than untreated fruit [76]. A chitosan-oil dip for peppers improved storage quality after 35 days at $8{ }^{\circ} \mathrm{C}$ due to smoother skin surface, better sensory quality, and increases in certain antioxidant enzymes [77]. Chitosan mixed with edible coatings reduced disease severity on bell peppers and improved storage quality by increasing firmness, reducing weight loss, and reducing disease [50]; general decay was reduced below $5 \%$, although specific disease-causing agents were not recorded. Waxes and edible coatings are known to improve certain quality characteristics of fruiting vegetables postharvest such as firmness and reduce water loss [78,79]. Adding chitosan or other biopreparations to these coatings has been shown to be beneficial in postharvest produce storage $[50,80]$. Wax mixtures with natural fungicidal compounds have been tested on citrus to reduce the reliance on synthetic chemistries [81] and could be adopted to pepper postharvest.

\subsection{Calcium and Natural Compounds}

The prevalence of calcium, low cost, and effectiveness make this an optimum postharvest treatment for gray mold control. High calcium content in plant tissues is known to reduce $B$. cinerea severity [19], and calcium is an important natural fungicide alternative for control of gray mold $[82,83]$. Increasing tissue calcium content increases cross linking of polygalacturonate polymers and reduces damage from decay causing organisms [84]. Fungal polygalacturonase is also inhibited by calcium [85]. Kamara et al. [86] found that calcium chloride sprays reduced gray mold severity and increased the storage life of Egyptian pepper cultivars. Apples were protected from Botrytis fruit rot postharvest by a calcium $(2 \%)$ dip prior to storage [87]. Postharvest dips of calcium may also be beneficial for peppers during the postharvest washing and packaging process $[2,55,88]$. Calcium-containing salts tested in vitro against $B$. cinerea from pepper demonstrated that calcium hydroxide was the most effective at controlling the pathogen [89]. Other researchers have highlighted the importance of combining calcium compounds and biocontrol agents to improve disease control. For example, Botrytis fruit rot of pear was significantly reduced when $\mathrm{CaCl}_{2}$ and the yeast Cryptococcus laurentii were combined and spread over fruit wounds [90]. The authors noted that peroxidase activity in the fruits treated with calcium continually increased up to $96 \mathrm{~h}$ after application (the last time point recorded), suggesting an induced response of the fruit as well as a potential physical protection against the pathogen. Hydrogen peroxide (Sanosil), a GRAS-certified disinfestant, inhibited B. cinerea conidial germination and mycelial growth at 0.5 and $1.5 \%$, respectively [48]. Dipping red bell peppers for $60 \mathrm{~s}$ in a $0.5 \%$ solution improved storage quality and reduced decay. Vapors of acetic acid, a naturally derived acid, completely prevented Botrytis fruit rot of tomato and other fruits after $1 \mathrm{~h}$ exposure, and the treatment was effective at cool temperatures as low as $1{ }^{\circ} \mathrm{C}$ demonstrating usefulness in cool storage conditions [91]. Elad [51] sprayed different antioxidants known to scavenge free radicals onto pepper leaves and found that four provided significant reduction in B. cinerea at $0.1,1.0$, and $10 \mathrm{mM}$. Inhibition of ethylene production by the antioxidants may have played a role in the disease reduction observed due to the known effects of this compound on plant tissues and B. cinerea. Storage duration and quality of green bell peppers was greatly enhanced by delaying the ripening process with 
hexanal vapors [92]. Multiple fruit quality evaluations were made, including water loss and $\mathrm{CO}_{2}$ evolution, which decreased with hexanal treatments from 0.005 to $0.02 \% w / w$.

\subsection{Microbial Biological Control}

Numerous microorganisms have shown activity against $B$. cinerea and other frequently cited storage pathogens; however, limited research has been specifically conducted on control of postharvest fruit rots [39]. Microbial compounds are applied pre- or postharvest and may be used alone or with another compound [53]. Bacillus licheniformis reduced gray mold on tomato plants and flowers [93], and Trichoderma harzianum was able to significantly reduce B. cinerea development on beans [52]. Other microbial species such as Bacillus subtilis, Rhodosporidium paludigenum, and Pichia guilliermondii have provided control against Botrytis fruit rot of tomato [94-96]. The biocontrols can have direct action on the pathogen and activate the plant's defense response. Bacillus amyloliquefaciens effectively controlled gray mold of tomatoes [97]. This biocontrol has known PGPR qualities when sprayed on pepper plants [98] and improves antioxidant quality in the fruit [99]. Udalova, et al. [100] tested foliar sprays of a humic acid $(0.1 \%)$ product with and without B. subtilius on two pepper cultivars and found that there was a significant increase in overall yield, which may have been a result of plant activation. The fruits from treated plants also have had higher total carbohydrates, ascorbic acid, and dry matter (\%) at maturity. Microbial formulations that have a beneficial effect on plant health could be applied at optimal times to reduce gray mold. When the endophyte Beauveria bassiana was applied to the roots of tomato and chili pepper, it provided protection against foliar $B$. cinerea [101]. This area of plant protection needs further research to optimize formulations and application timing to improve disease control postharvest.

\subsection{Systemic Acquired Resistance}

The potential to spray resistance inducers near harvest to prevent postharvest rots would benefit farmers by reducing inputs and lowering the risk of surpassing MRLs. Resistance inducers benefit plant health and protect the fruit by increasing quantities of antifungal compounds, phytoalexins, or other protective factors [102]. Salicylic acid (SA) is a well-known activator of induced resistance in plants that has been researched to control bacterial and fungal plant pathogens [103]. SA, abscisic acid, and methyl jasmonate all acted as resistance inducers of peppers, reducing Botrytis gray mold severity in peppers harvested from plants treated with different concentrations of the SAR compounds [86]. Phenol content and defense related enzymes increased in fruits of all varieties tested, which may have increased resistance levels. Spraying pepper plants in the field with SA at $8 \mathrm{mM}$ and citric acid at $30 \mathrm{mM}$ reduced gray mold of peppers in storage [66] and mycelial growth of the pathogen was sensitive to SA in vitro. When bell peppers were sprayed at $50 \mathrm{~g} / \mathrm{L}$ with harpin protein, a known resistance activator, B. cinerea growth was reduced [59]. Greenhouse grown fruits from plants regularly sprayed with harpin protein had higher soluble solids and acidity [104]. These treatments can also extend the storage life of peppers under cool $\left(7^{\circ} \mathrm{C}\right)$ temperatures and modified atmosphere [105]. After application, resistance inducers likely increase the levels of certain antifungal compounds in the fruit. More research is needed to determine which SAR inducers enhance these compounds in the fruit and to what magnitude and duration.

\subsection{Heat Treatment and UV-C Application}

Heat treatment of pepper fruit postharvest prior to storage can directly inhibit pathogens and increase the resistance of the fruit $[106,107]$. Treating peppers with hot water at $55^{\circ} \mathrm{C}$ for $12 \mathrm{~s}$ reduced decay and improved storability [55]. Physical removal of spores and possible beneficial effects to the fruit's cuticle were suggested to have reduced disease (Figure 1). Heat treatments from 45 to $55{ }^{\circ} \mathrm{C}$ reduce spore germination and germ tube elongation. Using irradiation can reduce gray mold by killing pathogen spores and inhibiting latent infections. UV-C light was germicidal to B. cinerea conidia and prevented gray mold of 
bell pepper [108]. This treatment was also found to reduce damage from chilling injury and general decay from Alternaria spp. and B. cinerea [109]. More research is needed on this control strategy to determine practicality and economic feasibility for the pepper industry. Effects on pepper quality would also need to be tested on additional cultivars and fruit-types; high rates of UV-C applied to tomato resulted in undesirable effects on fruit color [110].

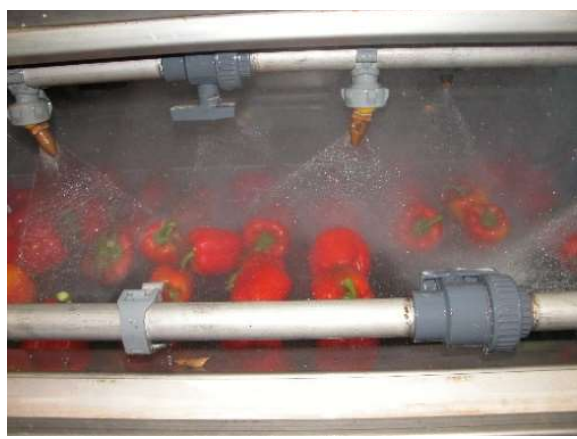

(A)

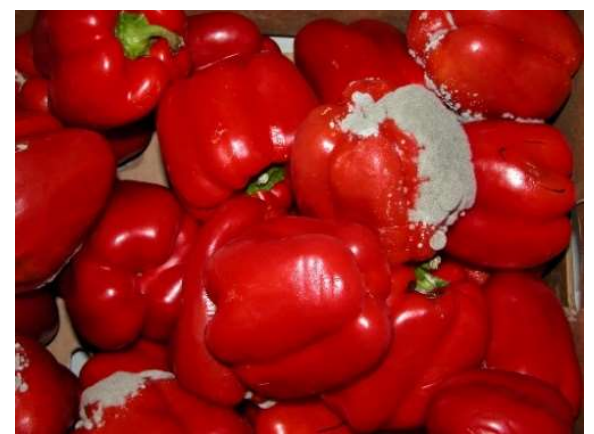

(B)

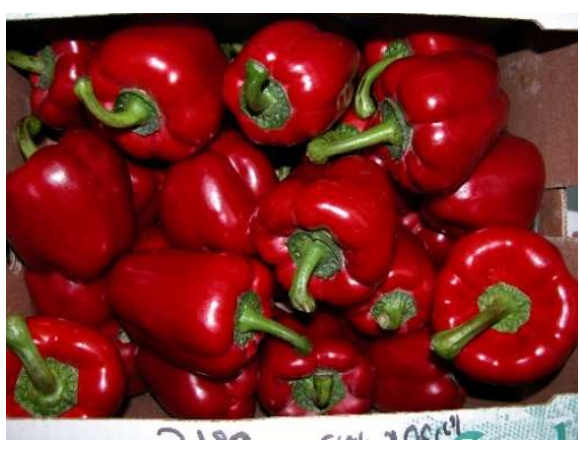

(C)

Figure 1. Postharvest processing and gray mold development in red peppers; (A) hot water $\left(55^{\circ} \mathrm{C}\right)$ rinse and brush of peppers; (B) gray mold after 3 weeks of storage $\left(7^{\circ} \mathrm{C}\right)$ without hot water treatment; (C) with hot water treatment.

\subsection{Packaging and Controlled Atmosphere}

Environmental regulation and temperature have a major effect on B. cinerea and disease development [111]. This is a well-established area of research, and in controlled agricultural settings, such as greenhouses, reducing relative humidity is known to limit gray mold during production [27]. In storage, RH levels and atmospheric conditions are largely dependent on the crop being stored and the quantity. Disease severity levels are reduced when storage containers are kept at low $\mathrm{O}_{2}$ and high $\mathrm{CO}_{2}$ levels [112]. In studies on controlled storage, the severity of gray mold of eggplant was reduced for fruits stored at $13{ }^{\circ} \mathrm{C}$ at $7.5 \% \mathrm{CO}$ and $1.5 \% \mathrm{O}_{2}$ [21]. Storage at $10{ }^{\circ} \mathrm{C}$ was found to significantly reduce rots of pepper compared to $21^{\circ} \mathrm{C}$ [113]. Although cold storage helps to reduce fungal diseases, it will not eliminate $B$. cinerea, especially where crops are held for long periods [114]. Peppers are typically washed after harvest, which can remove spores of $B$. cinerea but also contributes to high humidity in postharvest packaging. Typical packaging techniques for pepper may result in increased humidity during storage and transport unless perforations are used [115]. Artificially reducing the humidity in packaging for peppers greatly reduced B. cinerea and other pathogens [54]. Additionally, modifying packaging atmosphere using moisture absorbance packets greatly increased the storage of green bell peppers by reducing the respiration levels of the fruit [116]. Low temperatures in combination with modified atmosphere were important for maintaining high ascorbic acid content.

\section{Host Resistance}

Genetic host resistance is an important component of integrated disease management of specialty crops and has been used successfully against many diseases. Resistance to $B$. cinerea has proven to be challenging due to the aggressive nature of the pathogen; however, there are examples of successful breeding in some crops [117,118]. For vegetables, limited research has been conducted other than on tomatoes [119], where breeding techniques were used to introduce qualitative resistance [120]. Complete resistance to B. cinerea was not observed on other fruit crops and is likely difficult to find in wild host sources [121]. Breeding resistance into specialty crops is difficult due to the many stages during development at which B. cinerea can infect and the different mechanisms involved in the resistance response [122]. Pepper fruit resistance has not been looked at significantly. Kamara et al. [86] studied four local Egyptian pepper cultivars and found one that exhibited 
lower levels of gray mold after artificial inoculations. The mechanisms of this reduced susceptibility are not known. Additional extensive screening of cultivars and breeding efforts are needed to identify resistant fruit with desired horticultural traits.

\section{Capsacin and Phytoalexins}

Although not specifically associated with resistance, biological compounds in peppers may confer resistance during infection and improve the fruits resistance. Capsacin is a well-studied compound that is produced by hot peppers to give flavor and pungency and is only found in the genus Capsicum. Numerous factors affect capsacin production in the fruit, including the nutrition of the plant, the ability to produce peroxidase, and other host factors [123,124]. Xing et al. [125] found that capsaicin was inhibitory to B. cinerea in vitro, and that $\mathrm{pH} 5$ was the most optimum for growth inhibition. Substantial research on the production and metabolism of a similar metabolite capsidiol, a terpenoid phytoalexin, has demonstrated that it is important in resistance to certain pathogens of pepper and provides a source of resistance to non-pathogens [126-129]. Interestingly, B. cinerea is known to degrade capsidiol to less toxic compounds [130]. The role of this phytoalexin in susceptibility of pepper to Botrytis fruit rot is not completely clear. Other phytoalexins such as 6-methoxymellein from carrots can limit B. cinerea growth [131]. Enhancing metabolites within the fruit without negatively affecting fruit quality could improve postharvest storage duration. This is an important research area that needs more attention to ensure fruit quality remains high, even if fungicides or other biocontrols are not used.

\section{Conclusions}

B. cinerea remains a significant threat to bell peppers in postharvest storage and transport [7]. Although agrochemical use has decreased in some production settings, and research to find alternative methods of controlling pathogens has increased [34,39], fungicides are still used widely during production to control gray mold and other diseases of peppers. These practices will likely continue until satisfactory alternatives are found that are safe and provide disease control. The importance of $B$. cinerea as a postharvest pathogen complicates initiatives to reduce fungicides and the use of GRAS products due to the difficulties inherent in managing this important pathogen. High fruit quality and nutritious produce are essential for healthy diets, and society continues to focus on increasing produce consumption. Consumers remain concerned about fungicide residues on produce, and governmental restrictions are increasing in developed countries [36,132]. Additionally, environmental degradation due to extensive agrochemical use is an important factor in the need to find novel solutions. Natural products and resistance activators have been found to improve the postharvest quality of bell peppers and reduce gray mold severity in many studies, and continued research in this area is paramount. Despite the use and availability of natural and GRAS certified products and even the use of fungicides, $B$. cinerea remains a significant problem postharvest when conditions are favorable for disease. Future research needs to address this discrepancy so that bell peppers can be stored and transported without losses. Integrated control remains an important strategy and includes careful control of environmental conditions, sanitation, applying natural and GRAS products, and using fungicides judiciously to improve and maintain pepper quality postharvest.

Author Contributions: Writing-original draft preparation, C.K.; writing-review and editing, C.Z. All authors have read and agreed to the published version of the manuscript.

Funding: This work was funded by Israel Ministry of Agriculture and Rural Development, Grant no. 20-06-0103.

Institutional Review Board Statement: Not applicable.

Informed Consent Statement: Not applicable.

Data Availability Statement: Not applicable.

Acknowledgments: The authors thank Eleazar Fallik for the photographs of Figure 1. 
Conflicts of Interest: The authors declare no conflict of interest.

\section{References}

1. Bosland, P.W. Capsicums: Innovative uses of an ancient crop. In Progress in New Crops; Janick, J.J., Ed.; ASHS Press: Arlington, VA, USA, 1996; pp. 479-487.

2. Fallik, E.; Alkalai-Tuvia, S.; Parselan, Y.; Aharon, Z.; Elmann, A.; Offir, Y.; Matan, E.; Yehezkel, H.; Ratner, K.; Zur, N. Can colored shade nets maintain sweet pepper quality during storage and marketing? Acta Hortic. 2008, 830, 37-44. [CrossRef]

3. Gómez, R.; Pardo, J.E.; Navarro, F.; Varón, R. Colour differences in paprika pepper varieties (Capsicum annuum L.) cultivated in a greenhouse and in the open air. J. Sci. Food Agric. 1998, 77, 268-272. [CrossRef]

4. Yasuor, H.; Ben-Gal, A.; Yermiyahu, U.; Beit-Yannai, E.; Cohen, S. Nitrogen management of greenhouse pepper production: Agronomic, nutritional, and environmental implications. HortScience 2013, 48, 1241-1249. [CrossRef]

5. Legarrea, S.; Karnieli, A.; Fereres, A.; Weintraub, P.G. Comparison of UV-absorbing nets in pepper crops: Spectral Properties, effects on plants and pest control. Photochem. Photobiol. 2010, 86, 324-330. [CrossRef]

6. Pernezny, K.; Roberts, P.D.; Murphy, J.F.; Goldberg, N.P. Compendium of Pepper Diseases; APS Press: St. Paul, MN, USA, 2003.

7. Tzortzakis, N.; Alkan, N.; Ziv, C.; Korsten, L. Solanaceae and Cucurbitaceae crops. In Postharvest Pathology of Fresh Horticultur-al Produce; CRC Press: Boca Raton, FL, USA, 2019; pp. 303-338.

8. Tsitsigiannis, D.I.; Antoniou, P.P.; Tjamos, S.E.; Paplomatas, E.J. Major diseases of tomato, pepper and egg plant in green houses. Eur. J. Plant Sci. Biotechnol. 2008, 2, 106-124.

9. Rotem, J. Fungal diseases of potato and tomato in the Negev Desert. Plant Dis. 1981, 65, 315-318. [CrossRef]

10. Hausbeck, M.; Moorman, G. Managing Botrytis in greenhouse-grown flower crops. Plant Dis. 1996, 80, 1212-1219. [CrossRef]

11. Kelman, A. Introduction: The importance of research on the control of postharvest diseases of perishable food crops. Phytopathology 1989, 79, 1374.

12. Ceponis, M.; Cappellini, R.; Lightner, G. Disorders in fresh pepper shipments to the New York market, 1972-1984. Plant Dis. 1987, 71, 380-382.

13. Elad, Y.; Gullino, M.L.; Shtienberg, D.; Aloi, C. Managing Botrytis cinerea on tomatoes in greenhouses in the Mediterranean. Crop Prot. 1995, 14, 105-109. [CrossRef]

14. McColloch, L.P.; Cook, H.T.; Wright, W.R. Market Diseases of Tomatoes, Peppers, and Eggplant; Agricultural Research Service, US Department of Agriculture: Washington, DC, USA, 1982.

15. Naz, F.; Tariq, A.; Rauf, C.A.; Abbas, M.F.; Walsh, E.; Luo, J.; Kingsley, K.; Zhang, N.; Bennett, J. First report of Botrytis cinerea causing gray mold disease of bell pepper (Capsicum annuum) fruit in Pakistan. Plant Dis. 2018, 102, 1449. [CrossRef]

16. Jarvis, W. The dispersal of spores of Botrytis cinerea Fr. in a raspberry plantation. Trans. Brit. Mycol. Soc. 1962, 45, 549-559. [CrossRef]

17. López-Herrera, C. Levels of Airborne Botrytis cinerea Conidia Trapped Among Pepper (Capsicum annuum L.) and Eggplant (Solanum melongena L.) Crops Cultivated in Polyethylene Greenhouses on the Málaga Coastal Plain (Southern-Spain). J. Phytopathol. 1988, 122, 274-280. [CrossRef]

18. Park, S.-H.; Lee, J.-T.; Chung, S.-O.; Kim, H.-K. Forecasting the Pepper Gray Mold Rot to Predict the Initial Infection by Botry-tis cinerea in Greenhouse Conditions. Plant Pathol. J. 1999, 15, 158-161.

19. Elad, Y.; Shtienberg, D. Botrytis cinerea in greenhouse vegetables: Chemical, cultural, physiological and biological controls and their integration. Integr. Pest Manag. Rev. 1995, 1, 15-29. [CrossRef]

20. O'neill, T.; Shtienberg, D.; Elad, Y. Effect of some host and microclimate factors on infection of tomato stems by Botrytis cinerea. Plant Dis. 1997, 81, 36-40. [CrossRef]

21. Reyes, A.A. Pathogenicity, Growth, and Sporulation of Mucor mucedo and Botrytis cinerea in Cold or CA Storage. HortScience 1990, 25, 549-552. [CrossRef]

22. Halfon-Meiri, A.; Rylski, I. Internal mold caused in sweet pepper by Alternaria alternata: Fungal ingress. Phytopathology 1983, 73, 67-70. [CrossRef]

23. Utkhede, R.; Mathur, S. Fusarium fruit rot of greenhouse sweet peppers in Canada. Plant Dis. 2003, 87, 100. [CrossRef]

24. Stommel, J.; Goth, R.; Haynes, K.; Kim, S. Pepper (Capsicum annuum) soft rot caused by Erwinia carotovora subsp. atroseptica. Plant Dis. 1996, 80, 1109-1112. [CrossRef]

25. Parsons, E.P.; Popopvsky, S.; Lohrey, G.T.; Alkalai-Tuvia, S.; Perzelan, Y.; Bosland, P.; Bebeli, P.J.; Paran, I.; Fallik, E.; Jenks, M.A. Fruit cuticle lipid composition and water loss in a diverse collection of pepper (Capsicum). Physiol. Plant. 2013, 149, 160-174. [CrossRef]

26. Weryszko-Chmielewska, E.; Michalojc, Z. Anatomical traits of sweet pepper (Capsicum annuum L.) fruit. Acta Agrobot. 2011, 64, 181-188. [CrossRef]

27. Hausbeck, M.; Pennypacker, S.; Stevenson, R. The use of forced heated air to manage Botrytis stem blight of geranium stock plants in a commercial greenhouse. Plant Dis. 1996, 80, 940-943. [CrossRef]

28. Elad, Y. Mechanisms involved in the biological control of Botrytis cinerea incited diseases. Eur. J. Plant Pathol. 1996, 102, 719-732. [CrossRef]

29. Purvis, A. Regulation and role of the alternative oxidase in chilling injury of green bell pepper (Capsicum annuum L.). Acta Hortic. 2000, 553, 289-292. [CrossRef] 
30. Biles, C.L.; Wall, M.M.; Blackstone, K. Morphological and physiological changes during maturation of New Mexican type peppers. J. Am. Soc. Hort. Sci. 1993, 118, 476-480. [CrossRef]

31. Li, Z.; Jennings, A. Worldwide regulations of standard values of pesticides for human health risk control: A review. Int. J. Environ. Res. Public Health 2017, 14, 826. [CrossRef]

32. Leroux, P.; Fritz, R.; Debieu, D.; Albertini, C.; Lanen, C.; Bach, J.; Gredt, M.; Chapeland, F. Mechanisms of resistance to fungi-cides in field strains of Botrytis cinerea. Pest Manag. Sci. 2002, 58, 876-888. [CrossRef] [PubMed]

33. Liu, S.; Fu, L.; Tan, H.; Jiang, J.; Che, Z.; Tian, Y.; Chen, G. Resistance to boscalid in Botrytis cinerea from greenhouse-grown tomato Plant Dis. 2021, 105, 628-635. [CrossRef] [PubMed]

34. Hillocks, R.J. Farming with fewer pesticides: EU pesticide review and resulting challenges for UK agriculture. Crop Prot. 2012, 31, 85-93. [CrossRef]

35. Popp, J.; Pető, K.; Nagy, J. Pesticide productivity and food security: A review. Agron. Sustain. Dev. 2013, 33, 243-255. [CrossRef]

36. Handford, C.E.; Elliott, C.T.; Campbell, K. A review of the global pesticide legislation and the scale of challenge in reaching the global harmonization of food safety standards. Integr. Environ. Assess. Manag. 2015, 11, 525-536. [CrossRef]

37. Baker, B.P.; Benbrook, C.M.; Iii, E.G.; Benbrook, K.L. Pesticide residues in conventional, integrated pest management (IPM)-grown and organic foods: Insights from three US data sets. Food Addit. Contam. 2002, 19, 427-446. [CrossRef] [PubMed]

38. Palou, L.; Ali, A.; Fallik, E.; Romanazzi, G. GRAS, plant-and animal-derived compounds as alternatives to conventional fun-gicides for the control of postharvest diseases of fresh horticultural produce. Postharvest Biol. Technol. 2016, 122, 41-52. [CrossRef]

39. Fravel, D. Commercialization and implementation of biocontrol. Annu. Rev. Phytopathol. 2005, 43, 337-359. [CrossRef]

40. Hermann, D.; Stenzel, K. FRAC mode-of-action classification and resistance risk of fungicides. In Modern Crop Protection Compounds; Jeschke, P., Witschel, M., Kramer, W., Schirmer, U., Eds.; Wiley-VCH Verlag GmbH \& Co.: Weinheim, Germany, 2019; Volume 2, pp. 589-608.

41. Raposo, R.; Gomez, V.; Urrutia, T.; Melgarejo, P. Fitness of Botrytis cinerea associated with dicarboximide resistance. Phyto-pathology 2000, 90, 1246-1249. [CrossRef]

42. Chapeland, F.; Fritz, R.; Lanen, C.; Gredt, M.; Leroux, P. Inheritance and mechanisms of resistance to anilinopyrimidine fun-gicides in Botrytis cinerea (Botryotinia fuckeliana). Pestic. Biochem. Phys. 1999, 64, 85-100. [CrossRef]

43. Yarden, O.; Katan, T. Mutations leading to substitutions at amino acids 198 and 200 of beta-tubulin that correlate with be-nomylresistance phenotypes of field strains of Botrytis cinerea. Phytopathology 1993, 83, 1478-1483. [CrossRef]

44. Stehmann, C.; De Waard, M.A. Sensitivity of populations of Botrytis cinerea to triazoles, benomyl and vinclozolin. Eur. J. Plant Pathol. 1996, 102, 171-180. [CrossRef]

45. Zhou, F.; Hu, H.Y.; Song, Y.L.; Gao, Y.Q.; Liu, Q.L.; Song, P.W.; Chen, E.Y.; Yu, Y.A.; Li, D.X.; Li, C.W. Biological characteris-tics and molecular mechanism of fludioxonil resistance in Botrytis cinerea from Henan Province of China. Plant Dis. 2020, 104, $1041-1047$. [CrossRef]

46. Myresiotis, C.; Karaoglanidis, G.; Tzavella-Klonari, K. Resistance of Botrytis cinerea isolates from vegetable crops to anilinopyrimidine, phenylpyrrole, hydroxyanilide, benzimidazole, and dicarboximide fungicides. Plant Dis. 2007, 91, 407-413. [CrossRef] [PubMed]

47. Amiri, A.; Heath, S.M.; Peres, N.A. Resistance to fluopyram, fluxapyroxad, and penthiopyrad in Botrytis cinerea from straw-berry. Plant Dis. 2014, 98, 532-539. [CrossRef]

48. Fallik, E.; Aharoni, Y.; Grinberg, S.; Copel, A.; Klein, J. Postharvest hydrogen peroxide treatment inhibits decay in eggplant and sweet red pepper. Crop Prot. 1994, 13, 451-454. [CrossRef]

49. Fallik, E.; Grinberg, S. Hinokitiol: A natural substance that controls postharvest diseases in eggplant and pepper fruits. Post-harvest Biol. Technol. 1992, 2, 137-144. [CrossRef]

50. Poverenov, E.; Zaitsev, Y.; Arnon, H.; Granit, R.; Alkalai-Tuvia, S.; Perzelan, Y.; Weinberg, T.; Fallik, E. Effects of a composite chitosan-gelatin edible coating on postharvest quality and storability of red bell peppers. Postharvest Biol. Technol. 2014, 96, 106-109. [CrossRef]

51. Elad, Y. The use of antioxidants (free radical scavengers) to control grey mould (Botrytis cinerea) and white mould (Sclerotinia sclerotiorum) in various crops. Plant Pathol. 1992, 41, 417-426. [CrossRef]

52. Elad, Y.; Kapat, A. The role of Trichoderma harzianum protease in the biocontrol of Botrytis cinerea. Eur. J. Plant Pathol. 1999, 105, 177-189. [CrossRef]

53. Wisniewski, M.E.; Wilson, C.L. Biological control of postharvest diseases of fruits and vegetables: Recent advances. HortScience 1992, 27, 94-98. [CrossRef]

54. Rodov, V.; Ben-Yehoshua, S.; Fierman, T.; Fang, D. Modified-humidity packaging reduces decay of harvested red bell pepper fruit. HortScience 1995, 30, 299-302. [CrossRef]

55. Fallik, E.; Grinberg, S.; Alkalai, S.; Yekutieli, O.; Wiseblum, A.; Regev, R.; Beres, H.; Bar-Lev, E. A unique rapid hot water treatment to improve storage quality of sweet pepper. Postharvest Biol. Technol. 1999, 15, 25-32. [CrossRef]

56. Tzortzakis, N.G. Impact of cinnamon oil-enrichment on microbial spoilage of fresh produce. Innov. Food Sci. Emerg. Technol. 2009, 10, 97-102. [CrossRef]

57. Vagelas, I.; Papachatzis, A.; Kalorizou, H.; Wogiatzi, E. Biological control of Botrytis fruit rot (gray mold) on strawberry and red pepper fruits by olive oil mill wastewater. Biotech. Biotechnol. Equip. 2009, 23, 1489-1491. [CrossRef] 
58. Fallik, E.; Grinberg, S.; Ziv, O. Potassium bicarbonate reduces postharvest decay development on bell pepper fruits. J. Hortic. Sci. 1997, 72, 35-41. [CrossRef]

59. Akbudak, N.; Tezcan, H.; Akbudak, B.; Seniz, V. The effect of harpin protein on plant growth parameters, leaf chlorophyll, leaf colour and percentage rotten fruit of pepper plants inoculated with Botrytis cinerea. Sci. Hortic. 2006, 109, 107-112. [CrossRef]

60. Luo, M.; Purdy, H.; Avis, T.J. Compost bacteria provide antifungal activity against grey mold and Alternaria rot on bell pepper fruit. Botany 2019, 97, 221-230. [CrossRef]

61. Yue, Q.; Shao, X.; Wei, Y.; Jiang, S.; Xu, F.; Wang, H.; Gao, H. Optimized preparation of tea tree oil complexation and their antifungal activity against Botrytis cinerea. Postharvest Biol. Technol. 2020, 162, 111114. [CrossRef]

62. Mohammadi, S.; Aroiee, H.; Aminifard, M.H.; Jahanbakhsh, V. In vitro and in vivo antifungal activates of the essential oils of various plants against strawberry grey mould disease agent Botrytis cinerea. Arch. Phytopathol. Plant Prot. 2012, 45, $2474-2484$. [CrossRef]

63. Wilson, C.; Solar, J.; El Ghaouth, A.; Wisniewski, M. Rapid evaluation of plant extracts and essential oils for antifungal activ-ity against Botrytis cinerea. Plant Dis. 1997, 81, 204-210. [CrossRef]

64. Wang, Y.; Liu, X.; Chen, T.; Xu, Y.; Tian, S. Antifungal effects of hinokitiol on development of Botrytis cinerea in vitro and in vivo. Postharvest Biol. Technol. 2020, 159, 111038. [CrossRef]

65. Tzortzakis, N.; Chrysargyris, A.; Sivakumar, D.; Loulakakis, K. Vapour or dipping applications of methyl jasmonate, vine-gar and sage oil for pepper fruit sanitation towards grey mould. Postharvest Biol. Technol. 2016, 118, 120-127. [CrossRef]

66. Mekawi, E.M.; Khafagi, E.Y.; Abdel-Rahman, F.A. Effect of pre-harvest application with some organic acids and plant oils on antioxidant properties and resistance to Botrytis cinerea in pepper fruits. Sci. Hortic. 2019, 257, 108736. [CrossRef]

67. Elad, Y.; Shtienberg, D. Effect of compost water extracts on grey mould (Botrytis cinerea). Crop Prot. 1994, 13, 109-114. [CrossRef]

68. Zhang, H.; Li, R.; Liu, W. Effects of chitin and its derivative chitosan on postharvest decay of fruits: A review. Int. J. Mol. Sci. 2011, 12, 917-934. [CrossRef]

69. El Ghaouth, A.; Arul, J.; Wilson, C.; Benhamou, N. Ultrastructural and cytochemical aspects of the effect of chitosan on decay of bell pepper fruit. Physiol. Mol. Plant Pathol. 1994, 44, 417-432. [CrossRef]

70. Liu, J.; Tian, S.; Meng, X.; Xu, Y. Effects of chitosan on control of postharvest diseases and physiological responses of tomato fruit. Postharvest Biol. Technol. 2007, 44, 300-306. [CrossRef]

71. Sharp, R.G. A review of the applications of chitin and its derivatives in agriculture to modify plant-microbial interactions and improve crop yields. Agronomy 2013, 3, 757-793. [CrossRef]

72. Krasnobaeva, I.; Kovalenko, N.; Popova, E. The effect of chitin on the biological activity of Bacillus subtilis strains. Plant Prot. News 2020, 103, 233-240. [CrossRef]

73. Chang, T.-H. Disease control efficacy of chitosan preparations against tomato leaf mold. Res. Plant Dis. 2009, 15, 248-253. [CrossRef]

74. Sharma, N.; Verma, U.; Awasthi, P. A combination of the yeast Candida utilis and chitosan controls fruit rot in tomato caused by Alternaria alternata (Fr.) Keissler and Geotrichum candidum Link ex Pers. J. Hortic. Sci. Biotechnol. 2006, 81, 1043-1051. [CrossRef]

75. Ben-Shalom, N.; Ardi, R.; Pinto, R.; Aki, C.; Fallik, E. Controlling gray mould caused by Botrytis cinerea in cucumber plants by means of chitosan. Crop Prot. 2003, 22, 285-290. [CrossRef]

76. Peralta-Ruiz, Y.; Tovar, C.D.G.; Sinning-Mangonez, A.; Coronell, E.A.; Marino, M.F.; Chaves-Lopez, C. Reduction of post-harvest quality loss and microbiological decay of tomato "Chonto" (Solanum lycopersicum L.) using chitosan-E essential oil-based edible coatings under low-temperature storage. Polymers 2020, 12, 1822. [CrossRef]

77. Xing, Y.; Li, X.; Xu, Q.; Yun, J.; Lu, Y.; Tang, Y. Effects of chitosan coating enriched with cinnamon oil on qualitative proper-ties of sweet pepper (Capsicum annuum L.). Food Chem. 2011, 124, 1443-1450. [CrossRef]

78. Mejía-Torres, S.; Vega-García, M.; Valverde-Juárez, J.; López-Valenzuela, J.; Caro-Corrales, J. Effect of wax application on the quality, lycopene content and chilling injury of tomato fruit. J. Food Qual. 2009, 32, 735-746. [CrossRef]

79. de Jesús Dávila-Aviña, J.E.; Villa-Rodríguez, J.; Cruz-Valenzuela, R.; Rodríguez-Armenta, M.; Espino-Díaz, M.; Ayala-Zavala, J.F.; González-Aguilar, G. Effect of edible coatings, storage time and maturity stage on overall quality of tomato fruits. Am. J. Agric. Biol. Sci. 2011, 6, 162-171. [CrossRef]

80. Dhall, R. Advances in edible coatings for fresh fruits and vegetables: A review. Crit. Rev. Food Sci. Nutr. 2013, 53, 435-450. [CrossRef] [PubMed]

81. Fan, F.; Tao, N.; Jia, L.; He, X. Use of citral incorporated in postharvest wax of citrus fruit as a botanical fungicide against Penicillium digitatum. Postharvest Biol. Technol. 2014, 90, 52-55. [CrossRef]

82. Sasanuma, I.; Suzuki, T. Effect of calcium on cell-wall degrading enzymes of Botrytis cinerea. Biosci. Biotechnol. Biochem. 2016, 80, 1730-1736. [CrossRef]

83. Bennett, K.; Jent, J.; Samarakoon, U.C.; Schnabel, G.; Faust, J.E. Reduction of Botrytis cinerea infection on petunia flowers fol-lowing calcium spray applications. HortScience 2020, 55, 188-191. [CrossRef]

84. Conway, W.S.; Sams, C.E.; McGuire, R.; Kelman, A. Calcium treatment of apples and potatoes to reduce postharvest decay. Plant Dis. 1992, 76, 329-334. [CrossRef]

85. Chardonnet, C.O.; Sams, C.E.; Trigiano, R.N.; Conway, W.S. Variability of three isolates of Botrytis cinerea affects the inhibi-tory effects of calcium on this fungus. Phytopathology 2000, 90, 769-774. [CrossRef] 
86. Kamara, A.; El-Argawy, E.; Korany, A.E.; Amer, G. Potential of certain cultivars and resistance inducers to control gray mould (Botrytis cinerea) of pepper (Capsicum annuum L.). Afr. J. Microbiol. Res. 2016, 10, $1926-1937$.

87. Klein, J.D.; Conway, W.S.; Whitaker, B.D.; Sams, C.E. Botrytis cinerea decay in apples is inhibited by postharvest heat and cal-cium treatments. J. Am. Soc. Hort. Sci. 1997, 122, 91-94. [CrossRef]

88. Fallik, E.; Grinberg, S.; Alkalai, S.; Lurie, S. The effectiveness of postharvest hot water dipping on the control of grey and black moulds in sweet red pepper (Capsicum annuum). Plant Pathol. 1996, 45, 644-649. [CrossRef]

89. Yoon, C.-S.; Yeoung, Y.-R.; Kim, B.-S. The suppressive effects of calcium compounds against Botrytis cinerea in paprika. Hortic. Sci. Technol. 2010, 28, 1072-1077.

90. Yu, T.; Yu, C.; Lu, H.; Zunun, M.; Chen, F.; Zhou, T.; Sheng, K.; Zheng, X. Effect of Cryptococcus laurentii and calcium chlo-ride on control of Penicillium expansum and Botrytis cinerea infections in pear fruit. Biol. Control 2012, 61, 169-175. [CrossRef]

91. Sholberg, P.; Gaunce, A. Fumigation of fruit with acetic acid to prevent postharvest decay. HortScience 1995, 30, 1271-1275. [CrossRef]

92. Cheema, A.; Padmanabhan, P.; Amer, A.; Parry, M.J.; Lim, L.-T.; Subramanian, J.; Paliyath, G. Postharvest hexanal vapor treatment delays ripening and enhances shelf life of greenhouse grown sweet bell pepper (Capsicum annum L.). Postharvest Biol. Technol. 2018, 136, 80-89. [CrossRef]

93. Lee, J.P.; Lee, S.-W.; Kim, C.S.; Son, J.H.; Song, J.H.; Lee, K.Y.; Kim, H.J.; Jung, S.J.; Moon, B.J. Evaluation of formulations of Bacillus licheniformis for the biological control of tomato gray mold caused by Botrytis cinerea. Biol. Control 2006, 37, 329-337. [CrossRef]

94. Kilani-Feki, O.; Khedher, S.B.; Dammak, M.; Kamoun, A.; Jabnoun-Khiareddine, H.; Daami-Remadi, M.; Tounsi, S. Im-provement of antifungal metabolites production by Bacillus subtilis V26 for biocontrol of tomato postharvest disease. Biol. Control 2016, 95, 73-82. [CrossRef]

95. Wang, Y.; Yu, T.; Xia, J.; Yu, D.; Wang, J.; Zheng, X. Biocontrol of postharvest gray mold of cherry tomatoes with the marine yeast Rhodosporidium paludigenum. Biol. Control 2010, 53, 178-182. [CrossRef]

96. Zhao, Y.; Tu, K.l.; Shao, X.; Jing, W.; Yang, J.; Su, Z. Biological control of the post-harvest pathogens Alternaria solani, Rhizopus stolonifer, and Botrytis cinerea on tomato fruit by Pichia guilliermondii. J. Hortic. Sci. Biotechnol. 2008, 83, 132-136. [CrossRef]

97. Mari, M.; Guizzardi, M.; Brunelli, M.; Folchi, A. Postharvest biological control of grey mould (Botrytis cinerea Pers.: Fr.) on fresh-market tomatoes with Bacillus amyloliquefaciens. Crop Prot. 1996, 15, 699-705. [CrossRef]

98. Kazerooni, E.A.; Maharachchikumbura, S.S.; Al-Sadi, A.M.; Kang, S.-M.; Yun, B.-W.; Lee, I.-J. Biocontrol Potential of Bacillus amyloliquefaciens against Botrytis pelargonii and Alternaria alternata on Capsicum annuum. J. Fungi 2021, 7, 472. [CrossRef]

99. Cisternas-Jamet, J.; Salvatierra-Martínez, R.; Vega-Gálvez, A.; Stoll, A.; Uribe, E.; Goñi, M.G. Biochemical composition as a function of fruit maturity stage of bell pepper (Capsicum annum) inoculated with Bacillus amyloliquefaciens. Sci. Hortic. 2020, 263, 109107. [CrossRef]

100. Udalova, O.; Pishchik, V.; Mirskaya, G.; Vertebnyj, V.; Vorob'ev, N.; Khomyakov, Y.V. Effect of biologically active prepara-tions on productivity and quality of sweet pepper fruits in controlled conditions. Veg. Crops Russ. 2018, 3, 81-85. [CrossRef]

101. Barra-Bucarei, L.; France Iglesias, A.; Gerding González, M.; Silva Aguayo, G.; Carrasco-Fernández, J.; Castro, J.F.; Ortiz Campos, J. Antifungal activity of Beauveria bassiana endophyte against Botrytis cinerea in two solanaceae crops. Microorganisms $2020,8,65$. [CrossRef] [PubMed]

102. Terry, L.A.; Joyce, D.C. Elicitors of induced disease resistance in postharvest horticultural crops: A brief review. Postharvest Biol. Technol. 2004, 32, 1-13. [CrossRef]

103. Mandal, S.; Mallick, N.; Mitra, A. Salicylic acid-induced resistance to Fusarium oxysporum f. sp. lycopersici in tomato. Plant Physiol. Biochem. 2009, 47, 642-649. [CrossRef] [PubMed]

104. Tezcan, H.; Akbudak, N.; Şeniz, V. Effect of harpin protein on yield and fruit quality of pepper grown in greenhouse condi-tions. Acta Hortic. 2004, 729, 267-270.

105. Akbudak, N.; Akbudak, B.; Seniz, V.; Eris, A. Preharvest application of harpin on the cool storage life of pepper. Acta Hortic. 2006, 712, 517-522. [CrossRef]

106. Schirra, M.; D’hallewin, G.; Ben-Yehoshua, S.; Fallik, E. Host-pathogen interactions modulated by heat treatment. Postharvest Biol. Technol. 2000, 21, 71-85. [CrossRef]

107. Barkai-Golan, R.; Paster, N. Mycotoxins in Fruits and Vegetables; Elsevier Press: San Diego, CA, USA, 2011.

108. Mercier, J.; Baka, M.; Reddy, B.; Corcuff, R.; Arul, J. Shortwave ultraviolet irradiation for control of decay caused by Botrytis cinerea in bell pepper: Induced resistance and germicidal effects. J. Am. Soc. Hort. Sci. 2001, 126, 128-133. [CrossRef]

109. Vicente, A.R.; Pineda, C.; Lemoine, L.; Civello, P.M.; Martinez, G.A.; Chaves, A.R. UV-C treatments reduce decay, retain quality and alleviate chilling injury in pepper. Postharvest Biol. Technol. 2005, 35, 69-78. [CrossRef]

110. Liu, J.; Stevens, C.; Khan, V.; Lu, J.; Wilson, C.; Adeyeye, O.; Kabwe, M.; Pusey, P.; Chalutz, E.; Sultana, T. Application of ul-traviolet-C light on storage rots and ripening of tomatoes. J. Food Prot. 1993, 56, 868-873. [CrossRef] [PubMed]

111. Eden, M.; Hill, R.; Beresford, R.; Stewart, A. The influence of inoculum concentration, relative humidity, and temperature on infection of greenhouse tomatoes by Botrytis cinerea. Plant Pathol. 1996, 45, 795-806. [CrossRef]

112. Crisosto, C.H.; Garner, D.; Crisosto, G. Carbon dioxide-enriched atmospheres during cold storage limit losses from Botrytis but accelerate rachis browning of 'Redglobe' table grapes. Postharvest Biol. Technol. 2002, 26, 181-189. [CrossRef]

113. Carballo, S.J.; Blankenship, S.M.; Sanders, D.C.; Ritchie, D.F.; Boyette, M.D. Comparison of packing systems for injury and bacterial soft rot on bell pepper fruit. HortTechnology 1994, 4, 269-272. [CrossRef] 
114. Leifert, C.; Sigee, D.; Stanley, R.; Knight, C.; Epton, H. Biocontrol of Botrytis cinerea and Alternaria brassicicola on Dutch white cabbage by bacterial antagonists at cold-store temperatures. Plant Pathol. 1993, 42, 270-279. [CrossRef]

115. Meir, S.; Rosenberger, I.; Aharon, Z.; Grinberg, S.; Fallik, E. Improvement of the postharvest keeping quality and colour development of bell pepper (cv.'Maor') by packaging with polyethylene bags at a reduced temperature. Postharvest Biol. Technol. 1995, 5, 303-309. [CrossRef]

116. Singh, R.; Giri, S.; Kotwaliwale, N. Shelf-life enhancement of green bell pepper (Capsicum annuum L.) under active modified atmosphere storage. Food Packag. Shelf Life 2014, 1, 101-112. [CrossRef]

117. Tian, Y.; Che, Z.; Sun, D.; Yang, Y.; Lin, X.; Liu, S.; Liu, X.; Gao, J. Resistance identification of tree peony cultivars of different flowering time to gray mold pathogen Botrytis cinerea. HortScience 2019, 54, 328-330. [CrossRef]

118. Hammer, P.E.; Evensen, K.B. Differences between rose cultivars in susceptibility to infection by Botrytis cinerea. Phytopathology 1994, 84, 1305-1312. [CrossRef]

119. Williamson, B.; Tudzynski, B.; Tudzynski, P.; Van Kan, J.A. Botrytis cinerea: The cause of grey mould disease. Mol. Plant Pathol. 2007, 8, 561-580. [CrossRef] [PubMed]

120. Finkers, R.; van den Berg, P.; van Berloo, R.; ten Have, A.; van Heusden, A.W.; van Kan, J.A.L.; Lindhout, P. Three QTLs for Botrytis cinerea resistance in tomato. Theor. Appl. Genet. 2007, 114, 585-593. [CrossRef] [PubMed]

121. Wurms, K.V.; Long, P.G.; Sharrock, K.R.; Greenwood, D.R. The potential for resistance to Botrytis cinerea by kiwifruit. Crop Prot. 1999, 18, 427-435. [CrossRef]

122. Elad, Y.; Evensen, K. Physiological aspects of resistance to Botrytis cinerea. Phytopathology 1995, 85, 637-643. [CrossRef]

123. Díaz, J.; Pomar, F.; Bernal, A.; Merino, F. Peroxidases and the metabolism of capsaicin in Capsicum annuum L. Phytochem. Rev. 2004, 3, 141-157. [CrossRef]

124. Monforte-González, M.; Guzmán-Antonio, A.; Uuh-Chim, F.; Vázquez-Flota, F. Capsaicin accumulation is related to nitrate content in placentas of habanero peppers (Capsicum chinense Jacq.). J. Sci. Food Agric. 2010, 90, 764-768. [CrossRef]

125. Xing, F.; Cheng, G.; Yi, K. Study on the antimicrobial activities of the capsaicin microcapsules. J. Appl. Polym. Sci. 2006, 102, 1318-1321. [CrossRef]

126. Stoessl, A.; Unwin, C.; Ward, E. Postinfectional fungus inhibitors from plants: Fungal oxidation of capsidiol in pepper fruit. Phytopathology 1973, 63, 1225-1231. [CrossRef]

127. Stoessl, A.; Unwin, C.; Ward, E. Postinfectional Inhibitors from Plants: I. Capsidiol, an antifungal compound from Capsicum frutescens 1. J. Phytopathol. 1972, 74, 141-152. [CrossRef]

128. Ward, E.; Unwin, C.; Stoessl, A. Postinfectional inhibitors from plants. VII. Tolerance of capsidiol by fungal pathogens of pepper fruit. Can. J. Bot. 1973, 51, 2327-2332.

129. Hwang, B.K.; Kim, Y.J. Capsidiol production in pepper plants associated with age-related resistance to Phytophthora capsici. Plant Pathol. J. 1990, 6, 193-200.

130. Ward, E.; Stoessl, A. Postinfectional inhibitors from plants. III. Detoxification of capsidiol, an antifungal compound from peppers. Phytopathology 1972, 62, 1186-1187. [CrossRef]

131. Mercier, J.; Arul, J.; Julien, C. Effect of UV-C on phytoalexin accumulation and resistance to Botrytis cinerea in stored carrots. J. Phytopathol. 1993, 139, 17-25. [CrossRef]

132. Conway, W.S.; Sams, C.E.; Kelman, A. Enhancing the natural resistance of plant tissues to postharvest diseases through cal-cium applications. HortScience 1994, 29, 751-754. [CrossRef] 